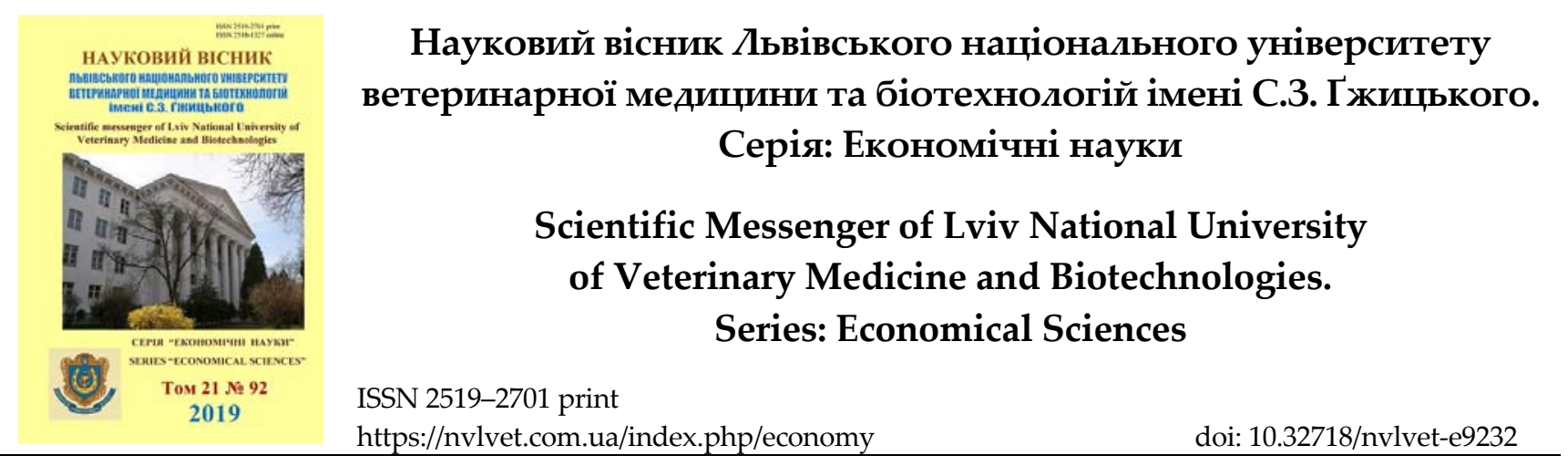

UDC 378.14:619:578/579

\title{
Visualization method in teaching veterinary microbiology, immunology and virology
}

\author{
G.I. Garagulya ${ }^{1}$, S.G. Matkovska ${ }^{1}$, I.I. Panikar ${ }^{2}$ \\ ${ }^{1}$ Kharkiv state zooveterinary academy, Kharkiv, Ukraine \\ ${ }^{2}$ Odessa State Agrarian University, Odessa, Ukraine
}

Article info

Received 14.02.2019

Received in revised form 18.03.2019

Accepted 19.03.2019

Kharkiv state zooveterinary academy, Mala Danilivka,

Dergachi district, Kharkiv region, 62341, Ukraine.

Tel.: +38-097-455-84-66

E-mail:vetvir.galina@gmail.com

Odessa State Agrarian University, Panteleymonyvska Str., 13 Odessa, 65012, Ukraine.
Garagulya, G.I., Matkovska, S.G., \& Panikar, I.I. (2019). Visualization method in teaching veterinary microbiology, immunology and virology. Scientific Messenger of Lviv National University of Veterinary Medicine and Biotechnologies. Series: Economical Sciences, 21(92), 180-185. doi: 10.32718/nvlvet-e9232

Pedagogical science has in its arsenal a number of methods of teaching educational information. Visibility is one of the main principles of didactics. There are auditory, visual and kinesthetic teaching methods. The task of the teacher is to develop and use such methods that allow the best way to convey information to the student. The article is devoted to the description of visual models developed by teachers of the Department of Microbiology, Virology and Immunology of the Kharkov State Zooveterinary Academy. The models allow visualization of various biological objects: blood cells and tissues of the animal's body, bacteria, viruses, molecules. Models are made of dense material and have a magnet. Due to this model is easily attached to the magnetic board. The models reflect the morphological and functional features of the depicted objects. Thus, the color of blood cells corresponds to their color in a smear, the color of bacteria - to a color when stained by Gram, and the different colors of molecules can mean their different function. Most often, models are used in the teaching of immunology. They help to visually show the various factors of immunity and their interactions. Using models, one can create illustrations of the most difficult topics: "Immune response", "The role of cytokines in the immune response", "Immunodeficiency and autoimmune diseases", "Serological reactions in the laboratory diagnosis of infectious diseases". The use of models helps in understanding information, its memorization and allows reflecting the dynamics of processes in immunology, virology and microbiology. To study the effect of the method of visual models on the quality of perception of educational information and analysis of the effectiveness of using models, we conducted a survey among students. The positive role of models in the study of veterinary microbiology, immunology and virology was noted by all students who participated in the survey.

Key words: teaching microbiology, virology and immunology, visual models of biological objects.

\section{Метод візуалізації у викладанні ветеринарної мікробіології, імунології та вірусології}

\author{
Г.І. Гарагуля ${ }^{1}$, С.Г. Матковська ${ }^{1}$, I.I. Панікар ${ }^{2}$ \\ ${ }^{1}$ Харківська державна зооветеринарна академія, м. Харків, Україна \\ ${ }^{2}$ Одеський державний аграрний університет, м. Одеса, Україна
}

\footnotetext{
Педагогічна наука має в своєму арсеналі ряд методик подання навчальної інформації. Існують аудіальні, візуальні, кінестетичні та полімодальні методи навчання, в яких інформачія представлена відповідно в слуховій, зоровій, моторній формі, або із комбінованою подачею інформачії. перед викладачем постає завдання розробити і використати такі методи, щзо дозволять найкраще донести інформачію до студента, в чому допомагає наочність, яка дає можливість перетворювати усну та письмову інформацію у візуальну форму. Стаття присвячена опису наочних моделей, розроблених авторами. Моделі дозволяють візуалізувати різні біологічні об 'єкти: клітини організму, бактерії, віруси, молекули. Моделі виконані із иупкого матеріалу та мають магніт, завдяки
} 
чому легко кріпляться до метало пластикової доики. Моделі відображають морфологічні та функціональні особливості відтворюваних біологічних об 'єктів. Колір моделей клітин крові відповідає їх забарвленню при фарбуванні за Романовським, а колір моделей бактерій - ̈̈х забарвленню при фарбуванні за Грамом, моделі молекул мають різний колір для відображення різної антигенної структури та різних функиій. Використання моделей допомагає в розумінні інформації, ї̈ запам'ятовуванні та дозволяє відображати динаміку процесів у ветеринарній імунології, вірусологї та мікробіології. При викладанні ветеринарної мікробіологї моделі дозволяють легко засвоїти особливості морфологї бактерій та їх тинкторіальні властивості. Найчастіше моделі використовуються в курсі ветеринарної імунологї. Вони дозволяють створити мобільні ілюстрацї практично до кожної теми лекцій та лабораторних занять. Це особливо важливо під час розгляду таких важких тем, як “Імунна відповідь та ії регуляція”, “Роль цитокінів в імунній відповіді”, “Імунодефіцити та аутоімунні хвороби”, “Серологічні реакиї в діагностиці патологї тварин”. Розроблені нами моделі полегшують сприйняття складних тем у вірусології, наприклад, “Репродукиія вірусів”, Антигенна структура вірусів» та інших. 3 метою вивчення впливу методу візуальних моделей на якість сприйняття навчальної інформації та аналізу ефективності використання моделей ми провели опитування серед студентів. Позитивну роль моделей у вивченні мікробіологї, імунологї та вірусологї відзначили усі опитані студенти.

Ключові слова: викладання мікробіологї, вірусологї, імунологї, наочні моделі біологічних об'єктів.

\section{Вступ}

Актуальність теми. Стан освіти є одним із факторів, що визначають тенденції розвитку суспільства. Освіта повинна забезпечити формування у студента сучасного рівня знань та умінь, що неможливо без підвищення якості їх засвоєння. Педагогічна наука має в своєму арсеналі ряд методик подання навчальної інформації. Існують аудіальні, візуальні, кінестетичні та полімодальні методи навчання, в яких інформація представлена відповідно в слуховій, зоровій, моторній формі, або із комбінованою подачею інформації (Sadovskaja, 2000).

Аналіз останніх досліджень $і$ публікаиій. Доведено, що у різних півкуль головного мозку людини різні функції. Права півкуля «відповідає» за образне мислення, за цілісне сприйняття, за сприйняття просторових форм, а ліва - за мову, логіку, роботу зі знаками. В абсолютної більшості людей права півкуля включається в роботу першою при ознайомленні 3 новою інформацією. Тому для успішного освоєння знань доцільним $\epsilon$ посилення наочно-образної складової матеріалу (Bezuhlyi, 2014). Отже, перед викладачем постає завдання розробити і використати такі методи, що дозволять найкраще донести інформацію до студента, в чому допомагає наочність, яка дає можливість перетворювати усну та письмову інформацію у візуальну форму (Sadovskaja, 2000).

У педагогіці наочність розуміють як один з основних принципів дидактики, відповідно до якого навчання базується на конкретних образах, що безпосередньо сприймаються суб'єктами навчання. Засоби візуальної наочності класифікують на 3 різновиди, а саме: натуральні (реальні явища, факти, предмети); зображувальні (картини, муляжі, копії); знаковосимвольні (формули, графіки, діаграми, схеми). Інструментами візуалізації $є$ різноманітні діаграми, а також графіки, матриці, карти та ілюстрації (малюнки, фото, моделі, відео) (Babych \& Semenikhina, 2014).

Використання наочних образів може перетворити наочність із допоміжного, ілюструючого засобу в провідний, продуктивний методичний засіб, що сприятиме кращому засвоєнню знань (Kolenkina, 2014). Термін “візуалізація" походить від латинського visualis - той, що сприймається очима, наочний. Одні автори вважають візуалізацію як готове представлення числової та текстової інформації у вигляді графіків, діаграм, таблиць, карт; інші стоять на позиції, що візуалізація - це процес представлення даних через зображення з метою максимальної зручності їх розуміння; надання видимої форми об'єкту, суб'єкту, процесу тощо (Babych \& Semenikhina, 2014). Візуалізацію розуміють як будь-який спосіб забезпечення можливості спостерігати реальність, а під візуальною моделлю розуміють будь-яку конструкцію, яка імітує сутність об'єкта пізнання і сприймається візуально (Raputo, 2019). Можна сказати, що найвища якість засвоєння інформації досягається за безпосереднього поєднання слова викладача та представленого учням зображення в процесі навчання (Puljaevskaja, 2016). Візуалізація інформації завдяки змістовому стисненню дозволяє подавати ії в компактній та зручній для використання формі. Такий метод враховує фізіологічні фактори зберігання інформації в мозку, що відбувається не лінійно, списком, аналогічно мові чи письму, а в переплетенні слів з символами, образами, відчуттями (Gorlicyna, 2012).

Понятійне і візуальне мислення на практиці знаходяться в постійній взаємодії. Вони, доповнюючи одне одного, розкривають різні сторони досліджуваного поняття, процесу або явища. Словесно-логічне мислення дає нам більш точне і узагальнене відображення дійсності, але це відображення є абстрактним. У свою чергу, візуальне мислення допомагає організувати образи, робить їх цілісними, узагальненими, повними (Bezuhlyi, 2014).

Мета роботи. Розробити, створити та використати у навчальному процесі візуальні моделі, які імітують основні об'єкти або структурні елементи, що розглядаються під час вивчення дисциплін на кафедрі мікробіології, вірусології та імунології Харківської державної зооветеринарної академії; провести опитування студентів щодо ефективності методу візуалізації навчальної інформації.

Завдання дослідження: 1)описати розроблений нами метод візуалізації навчального матеріалу при викладанні ветеринарної мікробіології, імунології та вірусології; 2)проаналізувати можливості підвищення якості засвоєння навчального матеріалу при використанні запропонованого методу.

\section{Матеріал і методи досліджень}

Матеріалом дослідження є методика викладання ветеринарних дисциплін: мікробіології, імунології та вірусології за допомогою візуальних моделей біологі- 
чних об'єктів. В ході дослідження використані такі методи: теоретичний аналіз педагогічної літератури, метод педагогічного експерименту, педагогічного моделювання та конструювання, а також метод анкетування.

\section{Результати та їх обговорення}

У 2018-2019 навчальному році в навчальному плані підготовки спеціалістів ветеринарного профілю поновлено як самостійну дисципліну предмет "Ветеринарна імунологія”. За досвідом нашої роботи у 2009-2012 роках, викладання ветеринарної імунології має свої особливості. Серед них багатовимірність дисципліни, широкі зв'язки імунології з такими науками як анатомія, гістологія, хімія, нормальна та патологічна фізіологія, генетика, інфекційні хвороби, алергологія, трансплантологія, імунопатологія, фармакологія та іншими. Важливими є два аспекти викладання імунології: 1) більшість студентів, які раніше вивчали імунологію, характеризували іiі як одну із дуже складних дисциплін; 2) з 120 годин, відведених на вивчення ветеринарної імунології, 60 годин - це самостійна робота студента. Тож викладач постає перед завданням максимально “ущільнити” інформацію без ії спрощення або скорочення. Необхідно, щоб нова інформація знаходила опору в колишніх знаннях і уявленнях, щоб інформація надходила в мозок різними каналами, структурувалася і утворювала у свідомості нові концептуальні мережі.

У вирішенні багатьох завдань під час викладання ветеринарної імунології, а також мікробіології та
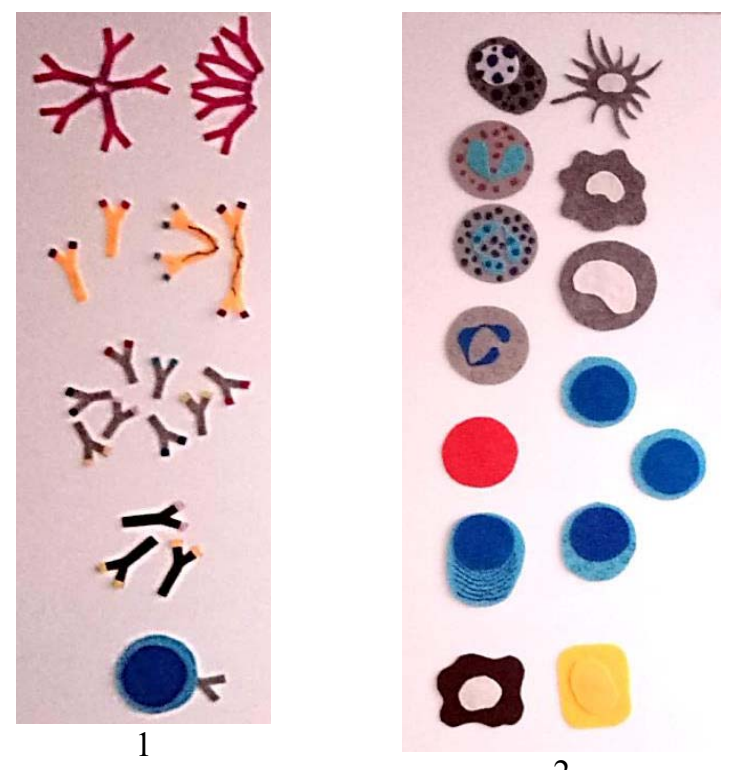

2 вірусології, на допомогу нам прийшли методи унаочнення навчальної інформації. Про використання окремих 3 них ми інформували в попередній статті (Harahulia \& Matkovska, 2017). Нове повідомлення стосується створення нового способу візуалізації навчальної інформації.

Серед засобів візуальної наочності нашу увагу привернула можливість використання моделей. Згідно 3 класифікацією, яку використовують в педагогіці, модель $є$ образна зображувальна (натуральна образотворча) наочність, інструментом якої $\epsilon$ ілюстрація, статистична за видом подання інформації. Візуальна модель повинна бути інформативною та адекватною тому навчальному матеріалу, що аналізується.

До початку навчального року ми розробили і створили із підсобних матеріалів ряд моделей, які дозволили через зображення надати видимої форми основним об'єктам, які вивчаються в курсах ветеринарної мікробіології, імунології та вірусології. Моделі клітин та антитіл являють собою пласкі предмети, вирізані із щільного нетканого кольорового матеріалу, на зворотній стороні яких прикріплено невеличкий магніт, моделі молекул - це синтетичні кульки з приклеєним магнітом. Розміри моделей клітин організму тварин 9 сантиметрів (діаметр), бактеріальних клітин - від 2,5 до 5,0 см в залежності від форми бактерії, довжина моделей антитіл різних класів - від 5 до 15 см, моделі молекул мають діаметр 1,5 см.

Аудиторії кафедри обладнані інтерактивними магнітними дошками. Завдяки магнітам моделі легко кріпляться до дошки. Серед сконструйованих є моделі клітин, вірусів та молекул (див. рис. 1 і табл. 1).

Рис. 1. Різновиди моделей: 1 - моделі імуноглобулінів різних класів; 2 - моделі клітин організму тварин; 3 - моделі бактеріальних клітин; 4 - моделі нуклеїнових кислот і молекул білків; 5 - модель вірусу 


\section{Таблиця 1}

Характеристика моделей, розроблених і створених для викладання ветеринарної мікробіології, імунології та вірусології

\begin{tabular}{|c|c|c|c|}
\hline Дисципліна & Об’єкт & Характеристика моделей & $\begin{array}{c}\text { Призначення (розділи дисциплі- } \\
\text { ни, де рекомендовано використо- } \\
\text { вувати моделі) }\end{array}$ \\
\hline \multirow{2}{*}{$\begin{array}{l}\text { Ветеринарна } \\
\text { мікробіологія }\end{array}$} & Бактерії & $\begin{array}{l}\text { Морфологія та тинкторіальні власти- } \\
\text { вості бактерій }\end{array}$ & Загальна мікробіологія \\
\hline & Бактерії & $\begin{array}{l}\text { Антигенна структура бактеріальних } \\
\text { клітин }\end{array}$ & Серологічні методи досліджень \\
\hline \multirow{5}{*}{$\begin{array}{l}\text { Ветеринарна } \\
\text { імунологія }\end{array}$} & Клітини & Імунокомпетентні клітини & \multirow{5}{*}{ Загальна і спеціальна імунологія } \\
\hline & Антигени & $\begin{array}{l}\text { Нормальн1 та 1нф1кован1 кл1тини } \\
\text { Різновиди антигенів }\end{array}$ & \\
\hline & Антитіла & $\begin{array}{l}\text { Різні класи антитіл } з \text { різною специфіч- } \\
\text { ністю }\end{array}$ & \\
\hline & Окремі & Комплемент, цитокіни, нуклеїнові & \\
\hline & молекули & кислоти & \\
\hline $\begin{array}{l}\text { Ветеринарна } \\
\text { вірусологія }\end{array}$ & Віруси & $\begin{array}{l}\text { Морфологія та антигенна структура } \\
\text { вірусів }\end{array}$ & Загальна і спеціальна вірусологія \\
\hline
\end{tabular}

Використання розроблених і створених моделей можна проілюструвати на конкретних прикладах вивчення окремих розділів та тем.

Однією 3 перших тем у вивченні мікробіології $\epsilon$ тема "Морфологія бактерій". Моделі бактеріальних клітин створені з врахуванням не лише пропорцій в їх розмірах, а й згідно з характером фарбування за Грамом, який $\epsilon$ найважливішим диференціальнодіагностичним методом фарбування бактерій. Такий підхід дає можливість пов'язати тему, яка розглядається у даний момент, з наступними темами і сформувати міцний зв'язок у засвоєнні інформації про морфологічні та тинкторіальні особливості різних груп бактерій (рис. 2).

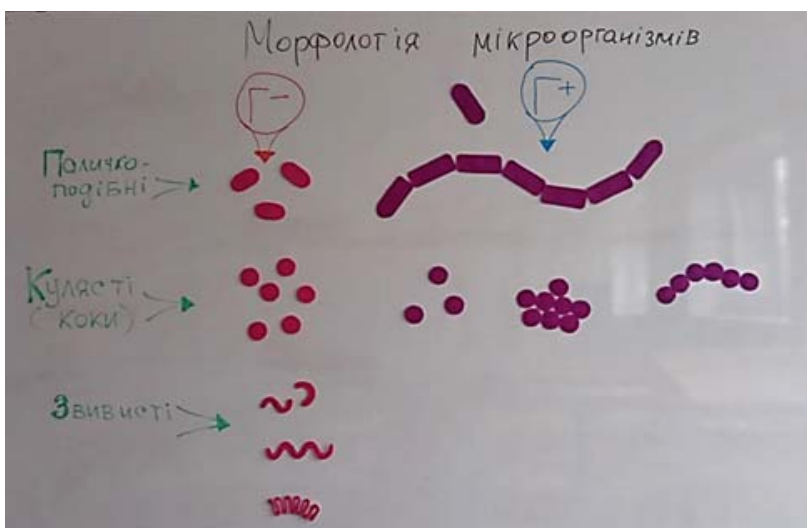

Рис. 2. Моделі бактерій в залежності від форми клітин та їх тинкторіальних властивостей

Складними для сприйняття студентами є теми розділів мікробіології та вірусології “Серологічні методи дослідження у діагностиці інфекційних хвороб”. Значно спрощують процес розуміння моделі бактерій та вірусів 3 різною антигенною структурою та моделі антитіл різної специфічності (рис. 3).

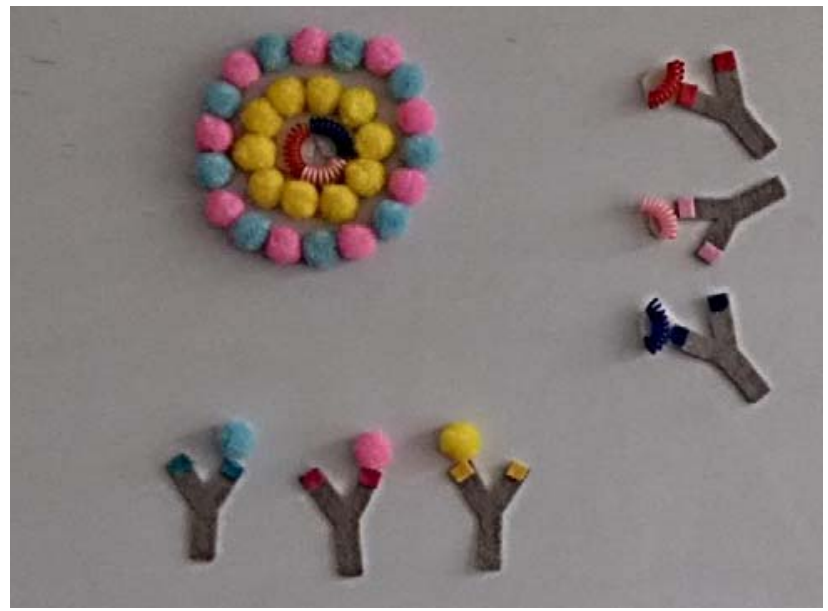

Рис. 3. Моделі антигенної структури вірусу i специфічних антитіл, які взаємодіють з відповідними компонентами вірусу

Створені нами моделі найбільш затребуваними є в курсі імунології. Практично кожне заняття можна унаочнювати за допомогою моделей клітин та речовин. Особливо це допомагає зрозуміти найскладніші імунологічні процеси, наприклад: взаємодія клітин в ході імунної відповіді, роль цитокінів в імунній відповіді, імунодефіцити, аутоімунні захворювання (див. рис. 4-5).

Метод візуалізації розглядається як представлення інформації, що сприяє “народженню” ідей, допомагає розібратися в складних поняттях, націлене на узагальнення і аналіз теорії та досвіду. Використання нових форм візуально-графічного відображення навчальної інформації актуалізує процеси розумової діяльності, як під час побудови, так і в процесі навчання та контролю, причому моделі виступають в якості матеріальної основи психічного образу, надаючи йому багатовимірність, наочність, лаконічність та стислість за умови зберігання змісту інформації (Sadovskaja, 2000; Gorlicyna, 2012; Bezuhlyi, 2014; Kolenkina, 2014; Raputo, 2019). 


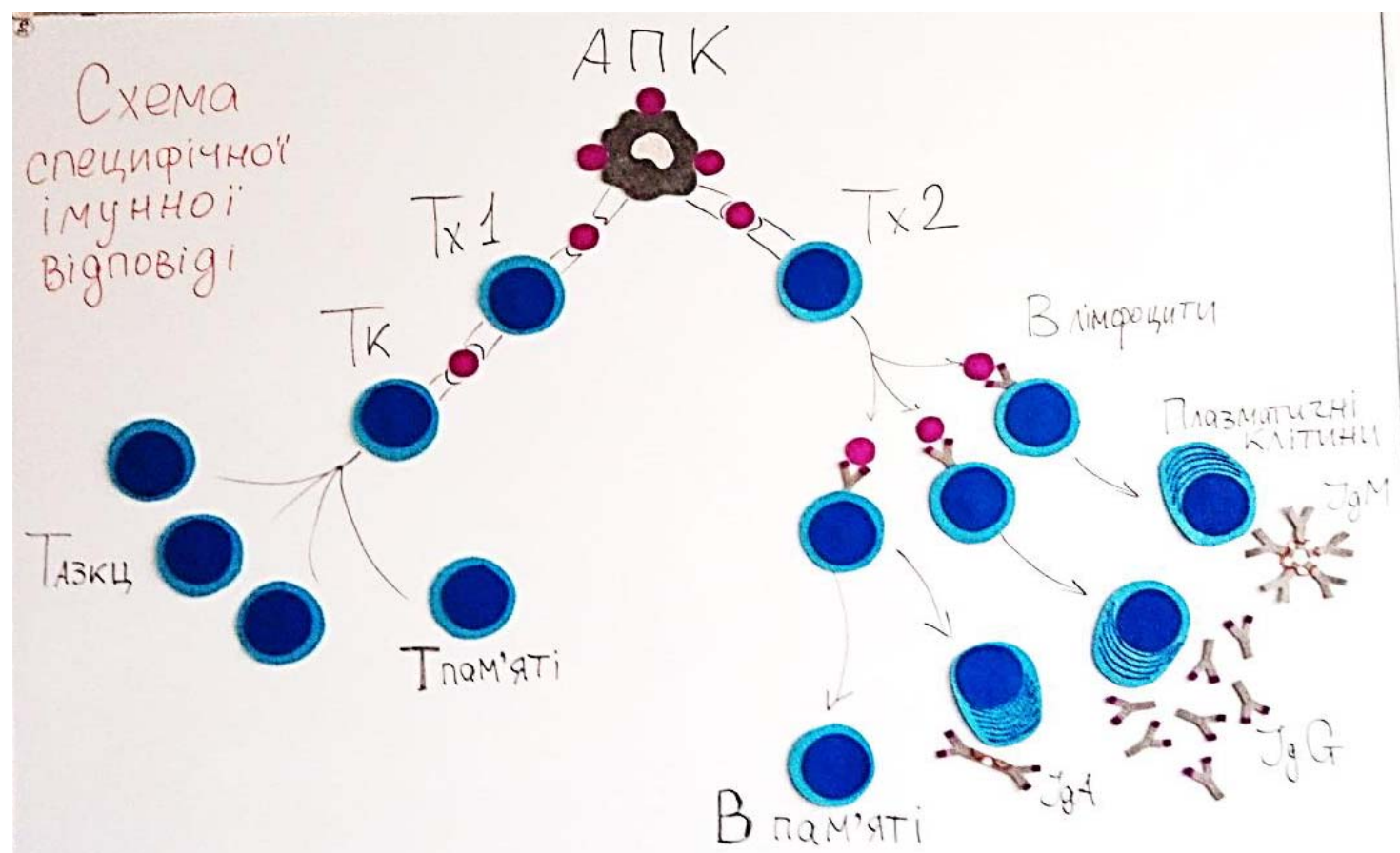

Рис. 4. Ілюстрація до теми “Специфічна імунна відповідь”

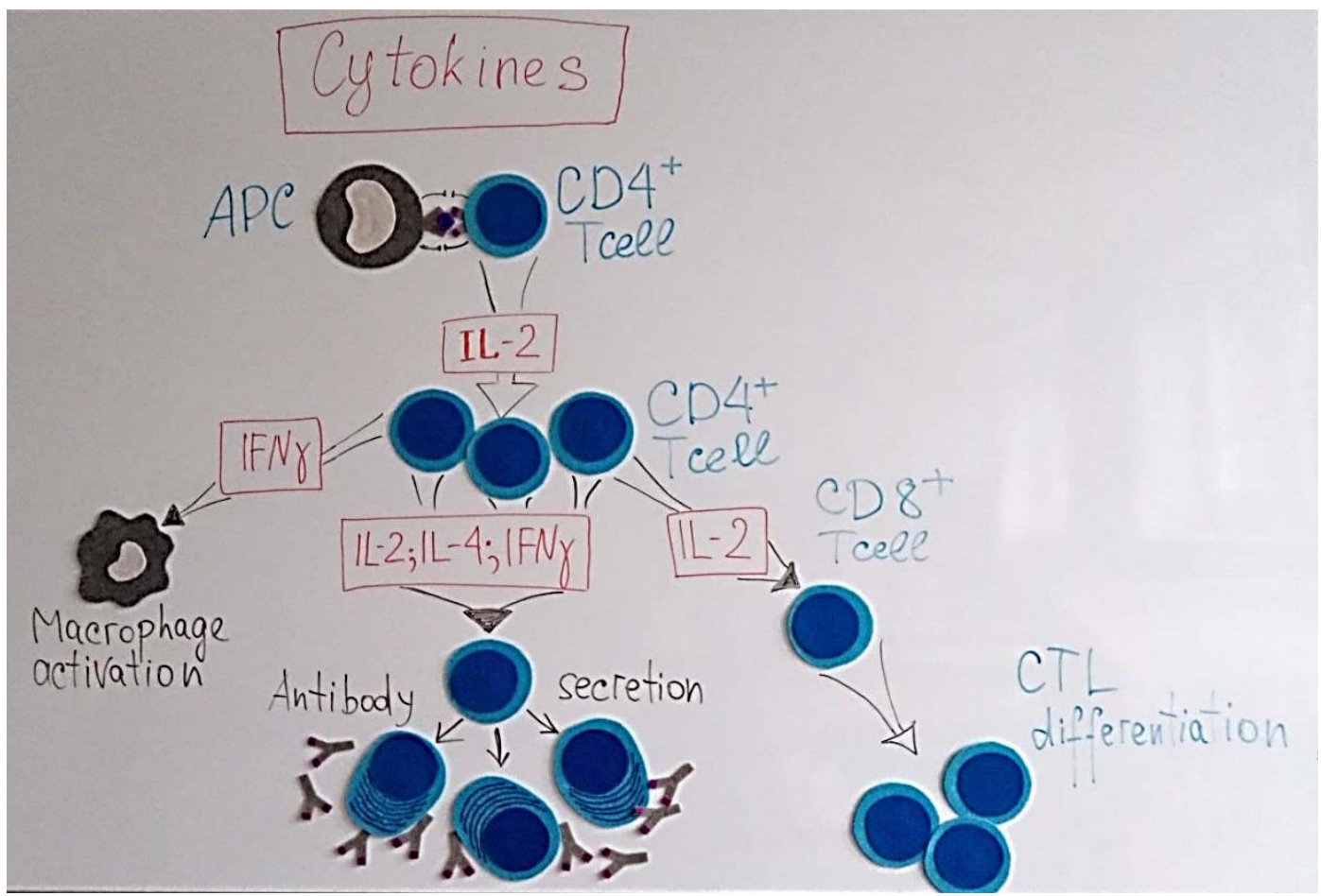

Рис. 5. Ілюстрація до теми "Роль цитокінів в імунній відповіді"

Для вивчення впливу методу візуальних моделей на якість сприйняття навчальної інформації ми провели опитування студентів з використанням анкет. Серед дванадцяти питань анкети половина стосувалась позитивного впливу, а половина - негативного. Серед критеріїв оцінки враховували зрозумілість (незрозумілість) та яскравість (непривабливість) моделей, можливість покращувати (або заважати) розумінню навчальної інформації, відображувати взаємодію біологічних об’єктів та динаміку процесів (чи відволікати від пояснення), а також об'єктивна необхідність використання моделей паралельно 3 ілюстраціями в лекціях та робочих зошитах.

В опитуванні взяли участь 66 студентів 2-3 курсів ФВМ, які вивчають імунологію та вірусологію. Серед опитуваних 98,5\% відмітили позитивний вплив моделей на процес засвоєння нової інформації, а саме: покращення розуміння і запам'ятовування як самих об’єктів вивчення, так і їх взаємодію, динаміку біологічних процесів. Вісім студентів відмітили недоліки методу: троє опитуваних $(4,5 \%)$ відмітили, що моделі частково відволікають від усного пояснення, четверо $(6,1 \%)$, що моделі не співпадають з власними уявлен- 
нями зображених об’єктів, і лише один студент (1,5\%) повідомив про недостатне розуміння призначення моделей, але відзначив їх зовнішню привабливість.

Практична значимість досліджень в тому, що вони полегшують засвоєння навчального матеріалу, створюють базу для модернізації навчальних посібників і вже впроваджені у навчальний процес на кафедpi.

\section{Висновки}

1. Метод унаочнення інформації за допомогою моделей сприяє створенню в свідомості студента візуального образу предметів, явищ та їх зв'язків.

2. Моделі використовуються у викладанні трьох дисциплін: ветеринарна мікробіологія, ветеринарна імунологія та ветеринарна вірусологія.

3. За результатами опитування студентів 2-3 курсів факультету ветеринарної медицини, використання візуалізації за допомогою моделей спрощує, покращує і активізує засвоєння навченої інформації: 98,5\% опитуваних відмітили позитивний вплив моделей на процес засвоєння нової інформації, 10,6\% - відмітили окремі негативні фактори.

Перспективи подальших досліджень. Подальші дослідження можуть бути пов'язані 3 вивченням впливу описаного методу викладання на якість засвоєння студентами навчального матеріалу, з метою удосконалення методів викладання.

\section{References}

Babych, O., \& Semenikhina, O. (2014). Do pytannia pro spivvidnoshennia poniat naochnist i vizualizatsiia // Fizyko-matematychna osvita. Naukovyi zhurnal. Sumy : SumDPU im. A.S.Makarenka, 2(3), 47-53. https://fmo-journal.fizmatsspu.sumy.ua/publ/4-1-0-21

Bezuhlyi, D. (2014). Pryiomy vizualnoho podannia navchalnoi informatsii. Fizykomatematychna osvita. Naukovyi zhurnal. Sumy: SumDPU im. A.S.Makarenka, 2(3), 7-15. https:// fmojournal.fizmatsspu.sumy.ua/publ/4-1-0-17 (in Ukrainian).

Gorlicyna, O.A. (2012). Obuchenie studentov pedvuzov vizualizacii znanij. Sovremennoe obrazovanie, 2, 1-9. doi: 10.7256/2306-4188.2012.2.336 (in Russian).

Harahulia, H.I., \& Matkovska, S.H. (2017). Metody optymizatsii zasvoiennia velykykh obiemiv informatsii v kursi "Veterynarna virusolohiia". Problemy zooinzhenerii ta veterynarnoi medytsyny: $\mathrm{Zb}$. nauk. prats KhDZVA, 34(2), 238-242 (in Ukrainian).

Kolenkina, I.N. (2014). Vizualizacija v obuchenii [jelektronnyj resurs]. Rezhim dostupu do statti: http://lib.teacher.msu.ru/pub/3052 (in Russian).

Puljaevskaja, A. (2016). Metody vizualizacii informacii [elektronnij resurs]. Rezhim dostupu do statti: http://nitforyou.com/metod-vizualizacia (in Russian).

Raputo, A.G. (2019). Vizualizacija kak neotemlemaja sostavljajushhaja processa obuchenija prepodavatelej [jelektronnyj resurs]. Rezhim dostupu do statti: http://econf.rae.ru/article/5147 (in Russian).

Sadovskaja, I.L. (2000). Metodika korrekcii usvoenija znanij $\mathrm{V}$ processe obuchenija biologii $\mathrm{V}$ pedagogicheskom vuze: avtoref. diss. ... kand. ped. nauk. Krasnojarsk (in Russian). 